\title{
Kebijakan Politik Pemerintahan Bojonegoro dalam Mengelola Sumber Daya Alam Minyak Bumi
}

\author{
Reny Yulianty \\ Pegawai Kecamatan Bourno, Kab. Bojonegoro \\ Reny_yulianty1996@yahoo.com \\ Diny Fitrhatin \\ Pendamping Desa, Kabupaten Tuban \\ dnyftrh@gmail.com
}

Received: 01 Juli 2020; Revised: 10 Juli 2020; Accepted : 20 Juli 2020; Published : Agustus 2020; Available online : Agustus 2020.

\begin{abstract}
Bojonegoro is a district with abundant natural resources (petroleum) and has been exploited since the colonial era until now, but until 2008 Bojonegoro is still the poorest area in East Java. But after 2008 under the leadership of Suyoto, Bojonegoro improved in managing its Natural Resources for the greatest prosperity of its people. Among the developments carried out by the Bojonegoro Regency Government after 2008 can be seen from several development indicators which include: Economic Growth, Poverty Rate, Sustainable Development Goals (SDGs), Open Government Partnership (OGP). Bojonegoro is an example of the success of the Regional Government in managing Natural Resources in the Regional Autonomy Region. This can be an example for other autonomous regions in managing natural resource management policies for the greatest prosperity of the people.
\end{abstract}

Keywords: Regional Autonomy, Natural Resource Management, Petroleum, Bojonegoro 


\section{Pendahuluan}

Pertamakali otonomi daerah mulai diwacanakan, ada kekhawatiran sekaligus optimisme yang berkembang saat itu. Optimisme berakar dari perubahan pola pembangunan dari lahirnya desentralisasi dari pusat ke daerah. Dalam arus optimisme mengalir pula kekhawatiran perubahan itu hanya memindahkan kebocoran dari pusat ke daerah, yang dalam banyak kasus terbukti nyata. Tidak sedikit pejabat daerah yang terbukti melakukan tindak pidana korupsi. Banyak kepala daerah yang berperilaku seperti raja-raja kecil. Maka dari itu, cukuplah alasan bagi mereka untuk mengatakan: desentralisasi di Indonesia telah kebablasan dan resentralisasi adalah keniscayaan. ${ }^{1}$

Ironisnya, pelaksanaan dibeberapa daerah bisa dikatakan gagal total sehingga yang dibutuhkan saat ini adalah evaluasi menyeluruh. Tetapi tidak semua daerah mengalami kegagalan, ada daerah yang berhasil mengembangkan sumber daya alam untuk pengurangan angka kemiskinan dan pengembangan

1 Purwo Santoso, Keluar dari Kekalutan Desentralisasi di Indonesia, Disampaikan dalam Seminar Daerah: Otonomi Daerah: Problematika dan Tantangannya, yang diselenggarakan oleh Program Studi Ilmu Pemerintahan, Fakultas Ilmu Sosial dan Ilmu Politik Univeritas Mulawarman, Samarinda pada tanggal 8 Mei 2014. pendidikan seperti Kabupaten Bojonegoro sekadar menyebutkan satu contoh bisa dijadikan proyek percontohan keberhasilan pelaksanaan otonomi daerah.

Dalam literatur kolonial Belanda, Bojonegoro selalu digambarkan sebagai salah satu daerah termiskin dan paling terbelakang di Jawa. Tanahnya tandus dan hampir tidak ada irigasi. Lahan pertanian Bojonegoro berkualitas buruk. Daerah yang subur di dekat Bengawan Solo juga sering menjadi sia-sia terkena banjir selama musim hujan. Bojonegoro disebut-sebut sebagai daerah yang secara sosial-ekonomi sangat terpuruk, karena setiap tahun dilanda bencana banjir dan kekeringan yang mengakibatkan produktifitas pertanian sangat rendah dan akibatnya sering kali penduduknya mengalami kemiskinan yang endemis serta kelaparan. ${ }^{2}$

Sejarah kemiskinan yang ada di Bojonegoro, berubah menjadi berkah saat ditemukannya Sumber Minyak oleh Lembaga Minyak dan Gas (LEMIGAS), sebuah lembaga studi yang menjadi bagian dari AKAMIGAS mengatakan bahwa Banyu Urip, Sukowati, Jambaran dan Alas Tua menyimpan kandungan

\footnotetext{
2 Penders, C.L.M. Bojonegoro 1900-1942. A.Story of EndemicPoverty in. North East Java Indonesia. (Singapura, Gunung Agung, 1984) Hlm. 34
} 
minyak mentah sampai 1,4 miliar barrel. Selain minyak mentah, blok Cepu juga memiliki kandungan gas sebesar 8,772 triliun kaki kubik. Sedangkan untuk gas, yang bisa diangkat sebesar $72 \% .^{3}$ Tetapi dengan ditemukannya ladang minyak tersebut sekaligus menjadi kutukan bagi Bojonegoro jika tidak bisa mengelolanya dengan arif dan bijaksana. Dalam acara Forum Akademisi untuk Migas di Jakarta, akhir 2015 lalu, Bupati Suyoto menyebutkan permasalahan dalam pengelolaan daerah bukan saja membangun rasa memiliki masyarakat dalam semua aspek, melainkan juga meningkatkan keterlibatan publik seluas-luasnya. ${ }^{4}$

Dari uraian di atas dapat di tarik permasalahan sebagai berikut: Bagaimana produk kebijakan di Bojonegoro dengan sejarah kemiskinan dan korupsi para pejabatnya bisa dengan baik mengelola Minyak Bumi. Apa dampak dari kebijakan tersebut bagi kesejahteran Masyarakat Bojonegoro.

\section{PEMBAHASAN}

\section{Kebijakan Pemerintah di Era Desentralisasi}

\footnotetext{
3 Tim Peneliti Kontras. Laporan Penelitian Bisnis Militer di Perusahaan Pengeboran Minyak Bojonegoro Jawa Timur. (Bojonegoro : Kontras, 2004). Hlm. 14

${ }^{4}$ Apridar. Desain Ulang Otonomi Daerah. Selasa, 3 Mei 2016 11:20 [Original Published by "Serambi Indonesia"]
}

Argumentasi pokok untuk menjawab pertanyaan mengapa diperlukan otonomi daerah atau desentralisasi dapat dijawab dengan mengacu pada adanya beberapa keragaman dari setiap daerah. Dengan desentralisasi maka pemerintah pusat dapat mengetahui secara jelas apa yang diperlukan oleh daerah untuk meningkatkan kesejahteraan masyarakatnya. Setiap wilayah di daerah mempunyai keunikan tersendiri dalam banyak hal seperti geografi, budaya, tingkat perkembangan ekonomi, potensi sumberdaya alam dan sebagainya. Tidak ada pemerintahan secara terpusat yang dapat membuat kebijakan dan program yang sama untuk setiap daerah untuk mencapai sasaran secara tepat. Karena itu melalui desentralisasi diharapkan masing-masing pemerintahan di setiap daerah dapat mengatasi permasalahannya dan memberi prioritas apa yang akan dikembangkan karena mereka sendiri yang mengetahui secara baik potensi alam yang tersedia beserta keinginan dan harapan-harapan masyarakatnya.

Satu hal yang diperlukan oleh setiap daerah dalam menjalankan Otonomi ialah, kepastian bahwa setiap daerah yang berotonomi dapat melangsungkan policy-making yang 
demokratis. Ini memiliki setidaknya dua makna. Pertama, policy making yang diperlukan adalah yang efektif dalam mengatasi masalah publik yang mengedepan atau teridentifikasi. Kedua, policy making tersebut semakin mengejawantahkan gagasan demokrasi. ${ }^{5}$ Kita tahu bahwa yang didambakan rakyat bukan hanya adanya pejabat daerah yang bisa berkuasa secara otonom dari pemerintah nasional, melainkan teratasinya masalah Indonesia dari daerah-daerah. Harus dipastikan kewenangan untuk mengurus dan mengatur rumah tangga daerah tumbuh dengan ekspresi semangat berdemokrasi. Dalam policy-making inilah proses berdemokrasi dan proses berotonomi daerah hadir sebagai paket two-in-one. Ini berarti bahwa, titik temu agenda demokratisasi dan desentralisasi adalah proses policy-making, dan titik temu ini tidak kita perlakukan sebagai titik strategis untuk mengoptimalkan pengelolaan kedua proses itu.

Sehubungan dengan hal itu harap dicatat bahwa, yang menjadi satu adalah penghayatannya dalam praktek. Lebih dari itu, yang harus menghati bukan hanya pejabat pemerintah melainkan rakyat yang menjadi pemilik

\footnotetext{
${ }^{5}$ Robert E. Goodin, "Democracy, Preferences and Paternalism," Policy Sciences, Vol. 26, No. 3, Democracy and the Policy Sciences (Aug., 1993).
}

pemerintahan daerah, yang sejauh ini belum merasa menjadi pemilik. Hal itu harus dimanifestasikan dalam proses dan rumusan kebijakan yang dibuat oleh pemerintah-pemerintah daerah. Ada kesulitan untuk memahami dan mengelola proses perubahan yang bukan hanya semakin mendasar melainkan juga semakin belum dikenali sebelumnya. Untuk itulah konsep transformasi dipakai untuk menggantikan konsep reformasi yang popular selama ini. Muara dari desentralisasi adalah terwujudnya pemerintahan yang demokratis berbasis otonomi daerah, bukan sekedar ada kepastian bahwa daerah tepatnya instansi dan pejabatpejabat pemerintah setempat memiliki cukup kewenangan untuk mengatur dan mengurus rumah tangaa sendiri. Demokrasi harus diwujudkan secara lebih nyata, lebih operasional dan lebih bernakna di level lokal, mulai dari wadah kelembagaan yang ada. ${ }^{6}$

Policy-making yang demokratis selanjutnya diharapkan dapat meningkatkan kemampuan masyarakat dan sumberdaya yang ada dimobilisasi dengan lebih baik. Dengan cara seperti ini maka program seperti pendidikan, pelayanan kesehatan, upaya rehabilitasi

\footnotetext{
${ }^{6}$ Purwo Santoso, Menolak Stagnasi Demokratisasi: Otonomi Daerah Sebagai Akualisasi dalam Riptek Vol.5 No.I Tahun 2011, Hal.: 45-60.
} 
hutan dan lahan, dan pembangunan pertanian dapat direalisasi lebih cepat dan lebih terarah. Bertumpu pada kemampuan lokal dari masyarakat dan sumberdaya ini maka upaya menolong diri sendiri akan lebih menonjol dalam mengatasi masalah lokal, tidak tergantung kepada bantuan dari pusat dan dari luar.

\section{Konteks Ekonomi Politik Daerah}

\section{Penghasil Minyak Bumi}

Di era otonomi daerah pula harapan dan kecemasan ini bersarang, persis ketika hubungan kekuasaan pusat dan daerah direorganisasikan. Dalam situasi baru ini pemerintah kabupaten memiliki kewenangan yang lebih besar untuk menyusun agenda, baik dalam menggali potensi daerah secara mandiri maupun mengelola urusan ekonomi dan pemerintahan secara relatif otonom. Aspirasi desentralisasi ditujukan agar jarak antara rakyat dan pembuat kebijakan menjadi lebih dekat baik secara politik maupun geografis. Sehingga memungkinkan rakyat berpartisipasi langsung dalam menyusun dan mengontrol kebijakan pemerintah daerah agar memenuhi hajat hidup rakyat.

Bagi daerah penghasil migas, harapan kemakmuran dicapai, dan sekaligus dibatasi oleh, ketentuan pemerintah pusat mengenai besarnya saham daerah dalam kerangka penyertaan modal (Participating Interest, PI) dan dana bagi hasil (DBH) yang diperoleh pemerintah daerah (pemda). Semakin besar persentase keduanya, semakin besar pula pendapatan yang diterima oleh pemda. Nampak jelas bahwa di era otonomi daerah, pengelolaan sektor migas adalah kebijakan yang tidak didesentralisasikan. Berdasarkan Undang-undang No 22 Tahun 2001 tentang Minyak dan Gas Bumi (Migas), pengelolaan dan pemanfaatan kekayaan migas adalah kewenangan pemerintah pusat baik dari segi pengaturan, pengawasan, pengelolaan dan pemanfaatannya. Dasar pertimbangannya adalah: "Bahwa minyak dan gas bumi merupakan sumber daya alam strategis tidak terbarukan yang dikuasai oleh negara serta merupakan komoditas vital yang menguasai hajat hidup orang banyak dan mempunyai peranan penting dalam perekonomian nasional sehingga pengelolaannya harus dapat secara maksimal memberikan kemakmuran dan kesejahteraan rakyat."

Konsepsi "dikuasai oleh negara" dapat dimaknai sebagai "dimiliki oleh negara", yaitu kepemilikan dalam arti yang luas, kepemilikan dalam pengertian 
hukum publik yang tentunya berfungsi sebagai sumber bagi pengertian kepemilikan perdata (private ownership). Bumi, air, dan seluruh kekayaan yang terkandung dalam perut bumi dan air tidak hanya dipahami dalam pengertian penguasaan melalui control dan fungsi regulasi semata. Dengan dikuasai oleh Negara, maka kekayaan sumber daya alam yang kita miliki, seluruhnya adalah untuk kepentingan seluruh rakyat. $^{7}$ Seiring dengan otonomi daerah dimana pemda menuntut untuk terlibat dalam pengelolaan sumberdaya alam di daerahnya, pemerintah pusat mengakomodir dengan pembagian saham penyertaan modal kepada daerah. Pemerintah pusat menerbitkan PP No. 35 Tahun 2004 tentang Kegiatan Usaha Hulu Minyak dan Gas Bumi yang memuat keharusan adanya Participating Interest sebesar $10 \%$ yang menjadi hak pemda yang pengelolaannya dijalankan oleh Badan Usaha Milik Daerah (BUMD), entah berupa Perusahaan Daerah (PD) atau Perseroan Terbatas (PT). Berdasarkan ketentuan, saham Perseroan Terbatas (PT) bisa dimiliki oleh Pemda, Perusahaan Daerah (PD), swasta dan masyarakat tetapi bagian terbesar dari saham Perseroan Terbatas

\footnotetext{
7 Jimly Asshiddiqie, Konstitusi Ekonomi, (Jakarta: Penerbit Buku Kompas, 2010), Hlm. 281
}

(PT) dimiliki oleh Pemda atau Perusahaan Daerah (PD). Pada dasarnya pengaturan hukum ini dimaksudkan untuk memberi peluang keterlibatan pemerintah daerah untuk mengelola kekayaan alam di wilayahnya sebagai konsekuensi eksploitasi kekayaan alam lokal tersebut oleh para investor.

Pembangunan harus memenuhi tiga komponen dasar yang dijadikan sebagai basis konseptual dan pedoman praktis dalam memahami pembangunan yang paling hakiki yaitu kecukupan (sustenance) memenuhi kebutuhan pokok, meningkatkan rasa harga diri atau jati diri (self esteem), serta kebebasan (freedom) untuk memilih. Pembangunan harus dipandang sebagai suatu proses multidimensional yang mencakup berbagai perubahan mendasar atas struktur sosial, sikapsikap masyarakat, dan institusi-institusi nasional, disamping tetap mengejar akselerasi pertumbuhan ekonomi, penanganan ketimpangan pendapatan, serta pengentasan kemiskinan. Pembangunan harus mencerminkan perubahan total suatu masyarakat atau penyesuaian sistem sosial secara keseluruhan tanpa mengabaikan keragaman kebutuhan dasar dan keinginan individu maupun kelompokkelompok sosial yang ada didalamnya 
untuk bergerak maju menuju suatu kondisi kehidupan yang serba lebih baik secara material maupun spiritual. ${ }^{8}$

Potret Keberhasilan Pengelolaan Sumber Daya Alam (Minyak dan Gas) di Bojonegoro

Meski berlimpah sumber daya alam berupa Minyak Bumi sejak 1893 (Kontras, 2004:11) hingga sekarang, tetapi masyarakat Bojonegoro masa lalu masih terjerat kemiskinan, pemerintahan yang tidak berpihak rakyat. Akibatnya, hingga 2007 Bojonegoro adalah kabupaten termiskin nomer 3 di Jawa Timur (BPS, 2007). Berbagai permasalahan Bojonegoro : Kemiskinan Endemis, Korupsi di Pemerintahan, Infrastruktur dengan kualitas yang rendah, Pelayanan public dengan kualitas rendah, APBD yang rendah dan memiliki hutang dalam pembiayaan pembangunan, tidak ada ruang komunikasi antara pemerintah dan rakyat. Fokus ramainya isu pengelolaan cadangan migas baru-baru ini di Kabupaten Bojonegoro yang terkait dengan SDM di daerah. Mengingat orangorang yang tinggal di daerah dimana SDA ini berada merupakan pihak pertama yang lebih berhak merasakan hasil

\footnotetext{
${ }^{8}$ Todaro, M.P. dan Smith, Stephen C, Pembangunan Ekonomi di Dunia Ketiga, edisi Kedelapan, (New York: The Addison Wesley, 2003)
}

pengupayaan SDA, namun juga pihak pertama pula yang akan merasakan kemungkinan munculnya semua dampak negatif sebelum, selama dan sesudah aktifitas explorasi dan exploatasi SDA (masalah kejutan demografis dengan bertambahnya penduduk (pekerja) sementara, kejutan infrastruktur sosial karena kultur hidup yang akan berubah, masalah lingkungan akibat exploatasi SDA dan lain sebagainya).

Keberhasilan Pemerintahan Kabupaten Bojonegoro dalam meminimalisir jurang pengetahuan yang begitu besar antara pelaku industri migas yang memang sangat profesional dibidangnya dengan SDM daerah. Pada gilirannya, semakin kecilnya jurang pengetahuan ini, dalam batasbatas tertentu, akan semakin menambah semangat daerah untuk memajukan dirinya melalui aktifitas-aktifitas mandiri dalam proses pengelolaan dan pemanfaatan SDA yang dalam hal ini bisa diakomodasi oleh SDI daerah. Keberlangsungan hubungan SDA, SDI, SDM yang berkelanjutan akan sulit terwujud jika tidak ada komitmen yang tulus dari semua pihak yang berperan dalam aktifitas pengelolaan SDA dalam pengembangan, pemberdayaan dan pemanfaatan SDM daerah. Masingmasing mempunyai fungsi yang bisa 
digambarkan sebagai berikut: industri pengelola (seperti Pertamina, ExxonMobil, PetroChina, dan lain sebagainya) adalah eksekutor sekaligus pengelola yang profesional SDA dan pemerintah (baik di pusat dan terutama dalam kewenangan tertentu- di daerah) adalah regulator dan pengontrol semua aktifitas eksekusi dan pengelolaan SDA.

Diantara kedua pihak, terletak SDM handal yang akan menjalankan perannya masing-masing. Jika sudah dikenal bahwa SDM dari pihak industri adalah SDM yang profesional, maka SDM daerah yang akan menyertai proses pengelolaan SDA di daerahnya juga harus profesional. Ini menuntut proses pendidikan dan pelatihan yang berkelanjutan. Perguruan Tinggi dan lembaga pendidikan ke-profesi-an lainnya mempunyai peran yang penting dalam konteks ini. Oleh karena itu, keikut sertaan pemerintah daerah dan, terutama, industri dalam berinvestasi di bidang pengembangan dan pemberdayaan SDM daerah patut disyukuri dan dijadikan maskot dalam upaya pengelolaan SDA yang adil, bermartabat dan berkelanjutan. Perguruan Tinggi (universitas) dan lembaga pendidikan ke-profesi-an, selain berperan sebagai tempat dididiknya SDM daerah dalam mengelola SDA, juga bisa berperan sebagai faktor dinamisator dan inovator dalam upaya pemetaan sumber daya alam melalui aktifitas penelitian dan pengembangan yang mengacu kepada kebutuhan lokal daerah. Rantai konglomerasi industri-pemdauniversitas ini bisa berperan sebagai SDI yang diharapkan mampu untuk menelorkan SDM-SDM daerah handal sebagai faktor kunci keberhasilan pengelolaan SDA.

Suksesnya rantai konglomerasi diatas hanya akan terwujud jika Pemda Jatim, melalui pengawalan dan pengawasan DPRD Jatim, mampu mengelaborasi fungsi partisipasinya menjadi fungsi:

- Akselerator:

proses

pembelajaran pengelolaan sumber daya migas oleh Pemerintah Daerah. Aktifitas eksplorasi dan produksi (EP) cadangan migas mencakup pekerjaan-pekerjaan teknis yang luas mulai dari aspek eksplorasi, pengembangan dan produksi lapangan migas. Di setiap tahapan pekerjaan teknis tersebut, Pemda sudah bisa berperan dengan cara menempatkan wakil-wakilnya dalam partisipasi interest pengelolaan Blok Cepu, untuk menyerap sebanyak mungkin 
teknologi dan menjadikannya sebagai aset kemampuan daerah. Secara teknis ini bisa terjadi jika Pemda Jatim, melalui wakilnya dalam PI, bisa menempatkan wakilnya sebagai representative pada posisi manajemen operasi, eksplorasi dan procurement ;

- Regulator: pengelolaan migas di wilayah kerja Jawa Timur dalam hal perimbangan pengawasan wewenang pusat dan daerah. Terbukanya kesempatan untuk berpartisipasi dalam pengelolaan suatu sumber daya migas, adanya akses untuk secara legal mengawasi sumber daya daerah dalam kerangka otonomi daerah, dan tingginya resiko (baik teknisgeologis, ekonomis, sosial dan politis) dari suatu pengelolaan sumber daya migas bisa menyebabkan munculnya ketimpangan perimbangan wewenang, khususnya antara pemerintah propinsi dan kabupaten sendiri terkait dengan regulasi pengelolaan sumber daya migas. Pemda dan dengan pengawalan DPRD Jatim diharapkan mampu untuk memerankan fungsi regulasinya disini dalam kerangka penyeimbangan wewenan

propinsi-kabupaten. Secara teknis ini bisa terjadi jika Pemda Jatim, melalui wakilnya dalam PI, bisa menempatkan wakilnya sebagai representative pada posisi PR serta manajemen aspek legal dan operasi;

- Mediator: kepentingan regional masyarakat Jawa Timur pada umumnya, dan kabupaten penghasil dan sekitarnya, pada khususnya. Telah disinggung diatas bahwa setiap aktifitas EP suatu lapangan akan mempunyai dampak baik positif dan negatif. Dampak positif dan negatif ini bisa dijadikan peluang dan tantangan dalam kerangka menyuarakan kepentingan daerah (baik kabupaten maupun propinsi).

Kepentingan masyarakat Jawa Timur, khususnya kabupaten Bojonegoro dan sekitarnya, akan bisa tersampaikan, jika Pemda Jatim melalui keterlibatan dalam pengelolaan Blok Cepu terlibat langsung secara personal dan interest dalam setiap pengambilan keputusan pemanfaatan hasil EP pada aspek pengembangan masyarakat. 
Secara teknis ini bisa terjadi jika Pemda Jatim, melalui wakilnya dalam PI, bisa menempatkan wakilnya sebagai representative pada posisi manajemen pengembangan masyarakat (community development management).

Tulisan ini berfokus pada periode tahun (2008-2016), karena sejak sebelum 2008 Bojonegoro di Bawah Kepemimpinan $\quad$ Santoso $^{9}$ tidak memberikan perubahan dan dampak yang signifikan dalam pengelolaan SDA terhadap pembangunan di Bojonegoro. Pasca 2008 Bojonegoro di pimpin oleh Bupati Bojonegoro Suyoto yang mempunyai visi menjadikan Bojonegoro sebagai daerah lumbung pangan dan energi dan membangun Bojonegoro berfokus pada: 1) pembangunan SDM; 2) pembangunan infrastruktur yang mendukung pertumbuhan ekonomi 3) pengelolaan fiskal berkelanjutan melalui dana abadi migas. Pengelolaan Bojonegoro dengan pemerintahan yang

\footnotetext{
${ }_{9}^{9}$ Menurut berita di laman Kompas.com Mantan Bupati Bojonegoro M. Santoso (70), menjadi terpinana kasus korupsi Anggaran Pendapatan dan Belanja Daerah Tahun 2007 senilai Rp 6 Miliar dan juga terjerat kasus korupsi dana pembebasan lahan Blok Cepu Rp. 3,8 Miliar, sehingga di vonis dengan hukuman penjara selama 6 Tahun. Di akses pada http://regional.kompas.com/read/2012/09/17 /21011021/twitter.com 09:55 WIB
}

transformative (Santono dkk, 2016). Kinerja pembangunan Kabupaten Bojonegoro selama di bawah kepemimpinan Bupati Suyoto akan dibahas dari beberapa indikator pembangunan yang meliputi: Pertumbuhan Ekonomi, Tingkat Kemiskinan, Sustainable Development Goals (SDGs), Open Government Partnership (OGP).

Pembangunan harus memenuhi tiga komponen dasar yang dijadikan sebagai basis konseptual dan pedoman praktis dalam memahami pembangunan yang paling hakiki yaitu kecukupan (sustenance) memenuhi kebutuhan pokok, meningkatkan rasa harga diri atau jati diri (self esteem), serta kebebasan (freedom) untuk memilih. Pembangunan harus dipandang sebagai suatu proses multidimensional yang mencakup berbagai perubahan mendasar atas struktur sosial, sikapsikap masyarakat, dan institusi-institusi nasional, disamping tetap mengejar akselerasi pertumbuhan ekonomi, penanganan ketimpangan pendapatan, serta pengentasan kemiskinan. Pembangunan harus mencerminkan perubahan total suatu masyarakat atau penyesuaian sistem sosial secara keseluruhan tanpa mengabaikan 
keragaman kebutuhan dasar dan keinginan individu maupun kelompokkelompok sosial yang ada didalamnya untuk bergerak maju menuju suatu kondisi kehidupan yang serba lebih baik secara material maupun spiritual (Todaro, 2003).

\section{Efek Pengelolaan Minyak dan Gas} terhadap Pembangunan di

\section{Bojonegoro}

Pembangunan ekonomi yang dilaksanakan baik di daerah perkotaan maupun daerah pedesaan dalam periode jangka waktu tertentu akan membawa suatu perubahan yaitu tingkat pertumbuhan ekonomi yang diikuti oleh perubahan-perubahan dalam struktur dan corak kegiatan ekonomi suatu wilayah atau yang lebih dikenal dengan perubahan struktur ekonomi. Struktur ekonomi dapat diartikan sebagai sebaran/distribusi dari masing-masing komponen yang membentuk ekonomi suatu wilayah dan biasanya disajikan dalam bentuk persentase.

Pertumbuhan ekonomi merupakan ukuran dinamis yang digunakan untuk melihat perubahan tingkat ekonomi antar periode. Perubahan ini diukur dengan satu ukuran / satu periode yang disebut kondisi ekonomi pada tahun dasar. Pertumbuhan ekonomi Bojonegoro secara umum dari tahun 2008 kian melesat menjadi Kabupaten yang memiliki pertumbuhan ekonomi tertinggi di Provinsi di Jawa Timur, bahkan secara nasional. Tabel dan grafik berikut ini memperlihatkan angka pertumbuhan ekonomi Kabupaten Bojonegoro, Provinsi Jawa Timur, dan pertumbuhan ekonomi Nasional. Laju pertumbuhan ekonomi adalah kenaikan PDRB tanpa memandang apakah kenaikan itu lebih besar atau lebih kecil (Sukirno, 2000). Pertumbuhan ekonomi merupakan indikator untuk melihat keberhasilan pembangunan dan merupakan syarat keharusan (necessary condition) bagi pengurangan tingkat kemiskinan. Adapun syarat kecukupannya ialah bahwa pertumbuhan ekonomi tersebut efektif dalam mengurangi tingkat kemiskinan.

Pertumbuhan Ekonomi dengan migas tahun 2015 tumbuh sebesar 19,87\% meningkat signifikan dibanding tahun 2014 karena meningkatnya lifting migas yang cukup besar di tahun 2015 mencapai 30 juta barel lebih atau meningkat sebesar $40 \%$ dibanding lifting tahun 2014. Pertumbuhan ekonomi tanpa migas tahun 2015 tumbuh sebesar $5,99 \%$ sedikit melambat dibanding tahun 2014 karena pengaruh perlambatan ekonomi global yang berpengaruh secara 
langsung disektor konstruksi, transportasi, jasa keuangan, real estate dan beberapa sektor lainnya. Hal inilah yang mendorong Suyoto, untuk menetapkan "peta jalan" (road map) agar setelah migas habis dari Bojonegoro, kabupaten ini masih dapat terus membangun secara berkelanjutan. Sejak memangku jabatan Bupati Bojonegoro periode 2008-2013, Suyoto langsung membenahi berbagai regulasi dalam pengelolaan dana bagi hasil migas. Pada tahun 2011, Kabupaten Bojonegoro menginisiasi peraturan daerah (perda) tentang ruang wilayah migas dan pertanian serta perda terkait pemberdayaan masyarakat lokal.

Pemkab dan DPRD kembali akan menerbitkan perda terkait pengolahan migas, yang diistilahkan sebagai dana abadi. Peraturan daerah ini akan disusun pada tahun 2016, khusus dana abadi mulai dianggarkan tahun ini sebesar Rp 100 miliar . Dana abadi ini berasal dari dua sumber utama yaitu dana bagi hasil dan bunga penyertaan saham (participating interest). Dari perhitungan kedua sumber pendapatan tersebut, Kabupaten Bojonegoro merencanakan mengumpulkan hingga Rp 20 triliun. Dengan dana abadi ini Kabupaten Bojonegoro saat ini memperbaiki dan menambah infrastruktur pendidikan secara bertahap. Selain diinvestasikan di sektor keuangan, dana abadi migas yang diterima oleh kabupaten dibelanjakan untuk pembangunan kualitas manusia. Pada tahun 2015, sekurangnya 12.000 warga Bojonegoro mengikuti pelatihan tenaga kerja kejuruan.

Publikasi Situs Resmi Pemkab Bojonegoro (www.bojonegorokab.go.id, 2017) menyampaikan beberapa hal saat menjadi narasumber dalam program Economic Challenges, dengan Tema Outlook 2015 dan proyeksi Migas 2016, di Metro TV bersama Menteri ESDM, Sudirman Said, dan Kepala SKK Migas, Amien Sunaryadi. Dua diantara tujuh point penting yang disepakati dalam diskusi tersebut adalah, pertama, Konsep dana abadi yang digagas Bojonegoro harus jalan meski produksi minyak belum maksimal dan harganya turun. Dengan konsep itu sedikit-sedikit dana dari DBH Migas mulai dikumpulkan sebagai dana abadi (petroleum fund) tahun 2016 dengan target Rp100 milyar; Kedua, tata kelola migas di daerah sudah harus masuk domain eksklusif dan tidak inklusif lagi, karena harus mengkaitkan antara konsep pertumbuhan ekonomi daerah (produk demostik regional bruto/PDRB naik) melalui industrialisasi hilir secara luas (foreward linkage) dengan membangun industri listrik, 
refinery (kilang mini), pupuk dan lainlain. Dengan berbagai kegiatan produksi tersebut akan menjadi berkah bagi ekonomi rakyat Bojonegoro.

\section{KESIMPULAN}

Kebijakan politik desentralisasi dan pelaksanaan Otonomi Daerah dalam skala besar-besaran yang telah berlangsung setidaknya selama 2 dekade terakhir. Tetapi tidak sedikit pejabat daerah yang terbukti melakukan tindak pidana korupsi serta banyak kepala daerah yang berperilaku seperti raja-raja kecil. Maka dari itu, cukuplah alasan bagi mereka untuk mengatakan: desentralisasi di Indonesia telah kebablasan. Tidak ada jaminan bahwa demokrasi bisa membudaya berkat pemberlakuan mekanisme dan tata kerja baru diantara para penyelenggara negara mengingat berbagai tatanan mekanistik yang diberlakukan begitu mudah di siasati dengan kiat-kiat politik dalam domain informal. Tetapi tidak semua daerah mengalami kegagalan, ada daerah yang berhasil mengembangkan sumber daya alam untuk pengurangan angka kemiskinan dan pengembangan pendidikan seperti Kabupaten Bojonegoro sekadar menyebutkan satu contoh bisa dijadikan proyek percontohan keberhasilan pelaksanaan otonomi daerah.
Bojonegoro merupakan kabupaten dengan Sumber Daya Alam (Minyak Bumi) yang melimpah dan sudah dieksploitasi sejak era jaman kolonial hingga sekarang, tetapi hingga 2008 Bojonegoro masih menjadi daerah termiskin di Jawa Timur. Tetapi pasca 2008 di bawah kepemimpinan Suyoto, Bojonegoro berbenah dalam mengelola Sumber Daya Alamnya untuk sebesarbesar kemakmuran rakyatnya. Diantaranya pembangunan yang dilakukan oleh Pemerintahan Kabupaten Bojonegoro pasca 2008 dapat dilihat dari beberapa indikator pembangunan yang meliputi: Pertumbuhan Ekonomi, Tingkat Kemiskinan, Sustainable Development Goals (SDGs), Open Government Partnership (OGP). Bojonegoro menjadi contoh dari keberhasilan Pemerintah Daerah dalam mengelola Sumber Daya Alam diera Otonomi Daerah. Hal ini bisa menjadi contoh bagi daerah-daerah otonom lain dalam mengelola kebijakan pengelolaan sumber daya alam guna sebesar-besar kemakmuran rakyat.

\section{Daftar Pustaka}

Apridar. 2016. Desain Ulang Otonomi Daerah. Selasa, 3 Mei 2016 11:20 [Original Published by "Serambi Indonesia"] 
Asshiddiqie, Jimly. 2010. Konstitusi Ekonomi. Jakarta: Penerbit Buku Kompas.

Goodin, Robert E. 1993. "Democracy, Preferences and Paternalism," Policy Sciences, Vol. 26, No. 3, Democracy and the Policy Sciences (Aug., 1993).

Marsh, David dan Gerry Stoker. 2002. Theory and Methods in Politial Science. Hampshire: Palgrave Macmilla.

Moleong, Lexy J. 2004. Metodologi Penelitian Kualitatif. Bandung: PT Remaja Rosdakarya.

Penders, C.L.M. 1984. Bojonegoro 19001942. A.Story of EndemicPoverty in. North East Java Indonesia. Singapura: Gunung Agung.

Santoso, Purwo. 2011. Menolak Stagnasi Demokratisasi: Otonomi Daerah Sebagai Akualisasi dalam Riptek Vol.5 No.I Tahun 2011.

Santoso, Purwo. 2014. Keluar dari Kekalutan Desentralisasi di Indonesia, Disampaikan dalam Seminar Daerah: Otonomi Daerah: Problematika dan Tantangannya, yang diselenggarakan oleh Program Studi Ilmu Pemerintahan, Fakultas Ilmu Sosial dan Ilmu Politik Univeritas Mulawarman,
Samarinda pada tanggal 8 Mei 2014.

Todaro, M.P. dan Smith, Stephen C. 2003. Pembangunan Ekonomi di Dunia Ketiga, edisi Kedelapan. New York: The Addison Wesley.

Tim Peneliti Kontras. Laporan Penelitian Bisnis Militer di Perusahaan Pengeboran Minyak Bojonegoro Jawa Timur. (Bojonegoro : Kontras, 2004). 